\title{
The analysis of non-conformances as the way of assessment of quality of aluminium finishing strips in the selected company
}

\author{
Edyta Kardas $^{1 *}$ \\ ${ }^{1}$ Czestochowa University of Technology, Faculty of Production Engineering and Materials \\ Technology, Department of Production Management and Logistics, al. Armii Krajowej 19, 42-201 \\ Czestochowa, Poland
}

\begin{abstract}
The main purpose of the paper is the analysis of nonconformances of aluminium finishing strips in one of Polish companies. This kind of analysis may be one of the ways to assess the quality of products. In the first part of the paper qualitative analysis of nonconformances of strips was made using the Pareto chart, where 6 types of non-conformances were taken into account. In the second part of the paper the causes and effects of non-conformances of strips were assessed using FMEA method. This method showed that the biggest problem concerned the anodised coating of strips. In the last part of the paper the in-depth analysis of the causes of appearance of defects if anodising process using Ishikawa chart was made. All causes were discussed. The analysis takes into account the results collected in the company producing various types of strips. The analysis covers the period of two calendar years.
\end{abstract}

\section{Introduction}

Quality is one of the most important issues in the contemporary world. It companies people in every sphere of their lives. It is important in the activity of production company and accompanies during each stage of the creation of product or service. Customer satisfaction, and thus the success of the company, depends mainly on the level of product quality [1].

Quality of products depends of many different factors, among others: the quality of choosing materials from which the product is made; the level of team of employees, workstations, machinery and equipment and production technology [2].

In order to maintain the appropriate level of production quality, its continuous observation, analysis of the collected results as well as the implementation of corrective and improvement measures should be made. Various methods and tools that can be used for this are helpful. They help to identify problems and their causes, and look for solutions that improve quality. They cause a clear division of responsibility for the quality and adapt the system to better manage organizational form. The quality information can be used not only by the control staff, but by all organizational units, thanks to which the impact on the quality of the product or service occurs at every stage of their performance [3-6].

*Corresponding author: ekonstan@wip.pcz.pl 
The literature presents a wide variety of quality management instruments, which can be used in various organizations. Their basic classification is shown in Table 1.

Table 1. Basic classification of quality management instruments [7].

\begin{tabular}{|c|c|c|c|}
\hline Principles & Methods & Tools & Techniques \\
\hline Team work & FMEA & Six sigma & Measurement \\
KAIZEN & QFD & 5 Why & Record \\
POKA-YOKE & SPC & Ishikawa chart & Organoleptic \\
Zero defects & DOE & Pareto chart & assessment \\
Quality management principles & 8D Report & Flow diagram & Research sheets \\
14 Deming's principles & $5 \mathrm{~S}$ & Shewhart's control cards & \\
Quality management principles & & Histogram & \\
used in the study and & & Brainstorm & \\
management of the object & & New quality tools & \\
\hline
\end{tabular}

Many publications present their use. They discuss use of such instruments in various organizations [8-11]. They also show examples of the use of specific instruments, such as e.g. Six Sigma [12-13]. It should be noted that their use is dictated by many diverse premises, among others: product life cycle stage, the type of problem being solved, size and type of organization, business profile, previous crew experience [8-15].

The main purpose of the paper is the analysis of non-conformances of aluminium finishing strips in one of Polish companies. This kind of analysis may be one of the ways to assess the quality of products. It usually concerns the analysis of the quality of finished products, but it can also be used during the production process to assess products in progress.

\section{Analysis of results}

The testing material taken to analysis are aluminium finishing strips with A02 profile. These are $120 \mathrm{~cm}$ long finishing strips, coloured in silver. Finishing strips, having the category of coating thickness AA15 $(15 \mu \mathrm{m})$, are made of anodised aluminium. They are used for aesthetic, as well as functional merging of floors, so that they create a chic and uniform whole. In most cases, they combine wooden floors, floor panels, parquet floors, with carpets or ceramic tiles as well as decorative stone [16].

In the paper the analysis of non-conformances of aluminium finishing strips was made. The analysis was divided into three parts: qualitative analysis of non-conformances of strips using Pareto chart, FMEA analysis of the problems of anodizing process and Ishikawa chart of causes of non-conformances. The analysis covers the period of two calendar year. Research was carried out in the Polish company that deals with the mechanical and surface treatment of aluminum, including the production of finishing strips.

In the company, apart from statistical tools, no quality instrument have been used earlier. Therefore, the use of three basic instruments was proposed: Pareto chart, FMEA and Ishikawa chart. This choice was dictated by two factors: economic - these methods were relatively cheap to use, their use in the company does not entail high costs associated with their use, and effective - these methods are quick and easy to use, and at the same time bring good results.

\subsection{Pareto chart of the causes of non-conformances of aluminium finishing strips}

The qualitative analysis of the causes of non-conformances of aluminium finishing strips was carried out. During the analysed period (two calendar year) six basic causes of nonconformances occurred: 1 - too thick coating, 2 - stains, 3 - pollution on the anodised 
surface, 4 - fingerprints on the anodised surface, 5 - damages on the anodised layer, 6 damages during transport [16].

Based on the number of non-conformances Pareto chart was made. This analysis sorted the causes of non-conformances from the most to the last frequent ones. The results of the analysis are presented in Fig. 1.

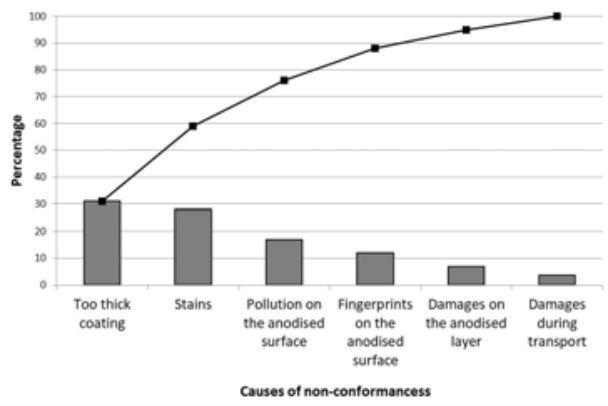

Fig. 1. Pareto chart of causes of non-conformances [Own study base on 16-17].

The results of the analysis presented in Fig. 1 indicate that the main causes of nonconformances are thickness of coating and stains on the profile. Non-conforming products included in these two groups are nearly $60 \%$ of total number. Causes of their appearance are the weakest points in the process of anodising finishing profiles.

\subsection{FMEA analysis of the causes of non-conformances of aluminium finishing strips}

The causes of the non-conformances are closely related to the problems occurring during the production process. Due to the series of performed operations and the specific properties of aluminium problems generated during profile anodizing process were subjected to a detailed examination. As a result, the most important factors were identified and based on these results the FMEA analysis were made. The results of the FMEA analysis are presented in Table 2.

Table 2. FMEA analysis of defects in profile anodizing process [Own study based on: 16-17].

\begin{tabular}{|c|c|c|c|c|c|c|c|c|}
\hline No. & Problem & Effect & Cause & 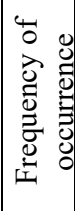 & 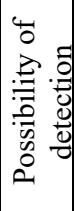 & 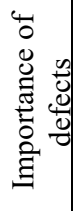 & 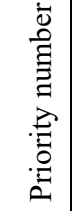 & Corrective actions \\
\hline 1 & $\begin{array}{l}\text { inadequate } \\
\text { coating } \\
\text { thickness }\end{array}$ & $\begin{array}{l}\text { too thick } \\
\text { coating }\end{array}$ & $\begin{array}{c}\text { too long } \\
\text { anodizing } \\
\text { time in } \\
\text { sulfuric acid }\end{array}$ & 5 & 3 & 7 & 105 & $\begin{array}{l}\text { adjust the anodizing time } \\
\text { to the customer's } \\
\text { guidelines }\end{array}$ \\
\hline 2 & $\begin{array}{c}\text { no } \\
\text { repeatability } \\
\text { of process } \\
\text { parameters }\end{array}$ & stains & $\begin{array}{l}\text { bathing } \\
\text { pollution }\end{array}$ & 4 & 1 & 8 & 32 & $\begin{array}{l}\text { frequent exchange of } \\
\text { scrubbers and changes in } \\
\text { process parameters }\end{array}$ \\
\hline 3 & $\begin{array}{c}\text { no } \\
\text { repeatability } \\
\text { of process } \\
\text { parameters }\end{array}$ & $\begin{array}{l}\text { pollution on } \\
\text { the anodized } \\
\text { surface }\end{array}$ & $\begin{array}{l}\text { too short } \\
\text { rinsing time }\end{array}$ & 3 & 3 & 7 & 63 & $\begin{array}{l}\text { increase the rinsing time } \\
\text { and changes in the } \\
\text { process parameters }\end{array}$ \\
\hline
\end{tabular}




\begin{tabular}{|c|c|c|c|c|c|c|c|c|}
\hline 4 & $\begin{array}{c}\text { no } \\
\text { repeatability } \\
\text { of process } \\
\text { parameters } \\
\text { fingerprints } \\
\text { on the } \\
\text { anodized } \\
\text { surface } \\
5\end{array}$ & $\begin{array}{c}\text { for a short } \\
\text { sealing time, } \\
\text { a low } \\
\text { amount } \\
\text { alfiseal 939 } \\
\text { mechanical } \\
\text { damage } \\
\text { damages on } \\
\text { the anodized } \\
\text { layer }\end{array}$ & $\begin{array}{c}\text { incorrect } \\
\text { suspension } \\
\text { or removal } \\
\text { of an item } \\
\text { from the } \\
\text { pendant }\end{array}$ & 2 & 4 & 7 & 56 & $\begin{array}{c}\text { maintain the sealing time } \\
\text { in accordance with the } \\
3 \text { min to } 1 \mu \text { m principle. } \\
\text { Increase the content of } \\
\text { alfiseal } 939\end{array}$ \\
\hline $\begin{array}{c}\text { inappropriate } \\
\text { material } \\
\text { protection } \\
\text { during } \\
\text { transport }\end{array}$ & $\begin{array}{c}\text { damages } \\
\text { during } \\
\text { transport } \\
\text { low quality } \\
\text { of protective } \\
\text { materials }\end{array}$ & 1 & 3 & 4 & 12 & $\begin{array}{c}\text { modify pendants } \\
\text { the supplier of the raw } \\
\text { material }\end{array}$ \\
\hline
\end{tabular}

Based on the FMEA analysis the main problem of anodizing process was diagnosed. Inadequate coating thickness was caused by the wrong anodizing time in sulfuric acid. To prevent the effect of this week point of the production process, the verification of anodizing process was carried out. The implementation of necessary changes in the process parameters was the most important corrective action. In order to maintain the proper anodizing time, additional preventive actions were implemented, such as employee trainings and additional technological process control.

\subsection{Ishikawa chart of causes of non-conformances}

After performing a detailed identification of non-conformances the analysis of causes of their appearance using Ishikawa chart was made. This graph helps to identify all factors that affect the finishing strips during anodising process. It allowed to gather and organize information in specific groups of causes (Fig. 2). Based on the results the following improving method of anodizing process of finishing strips should be implemented:

1. According to the group of Machine:

- Technical conditions - assessment of the technical condition of machinery and equipment on time may have a significant impact on the production volume,

- Producer - his goal should be to improve the quality and productivity of machines,

- Construction-technology - construction, and at the same time the technology used by the device manufacturer is of particular importance to the level of products.

2. According to the group of Measurement:

- Accuracy of the meter - the meter should indicate value of $0.01 \mu \mathrm{m}$ to examine accurately the thickness of the profile,

- Measurement method - it is important that the strips from each tested series wad tested in five places at equal distance from each other,

- Imprecision of the meter - inaccurate readings may disturb the actual value of data.

3. According to the group of Method:

- Anodizing program - the use of the appropriate anodising program is one of the basic factors determining the obtaining high quality of products,

- The course of anodizing process - performing the anodising process in accordance with the selected anodizing program,

- Way of hanging profiles - fasten the strips to the carriers in optimal way and using appropriate pendants, so that each element is coloured properly. 


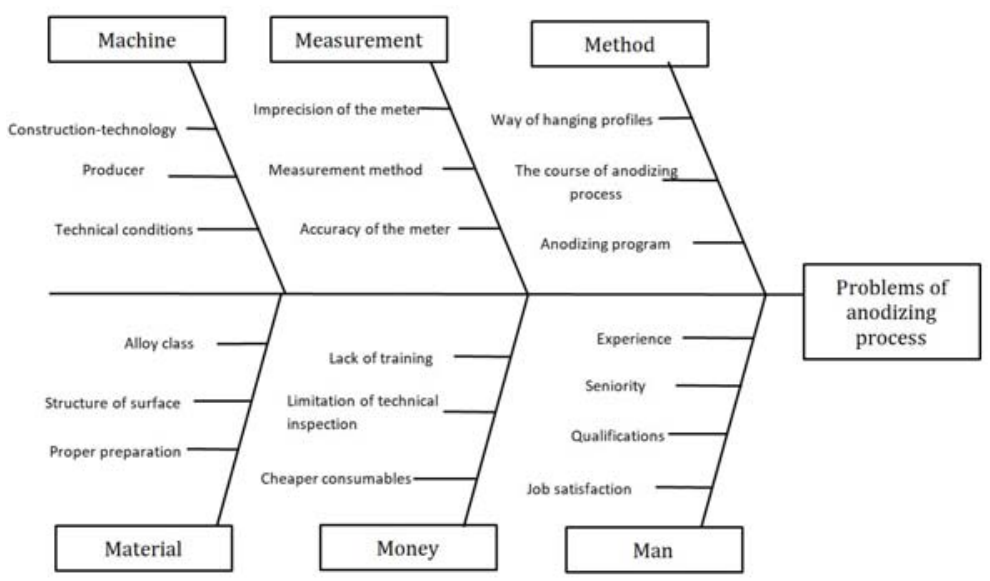

Fig. 2. Ishikawa chart of causes of problems of anodising process of finishing strips [Own study based on: 16-17].

4. According to the group of Material:

- Alloy class - it is important that used material is in the appropriate class of alloys, does not have a large amount of admixtures, what can significantly affect the aesthetics of the profile or prevent the process from being carried out.

- Structure of surface - the profile cannot have various types of blemishes (scratches, dents), this will worsen the appearance and aesthetics of the strips.

- Proper preparation - processes such as sanding or brushing must be performed by experienced workers, because it affects the final effect and the quality of the strips.

5. According to the group of Money:

- Lack of training - it is important to conduct periodic training to improve the employee's qualifications and professional skills,

- Limitation of technical inspection - a malfunctioning machine system can significantly reduce the production volume,

- Cheaper consumables - faster wear parts lead to frequent failures.

6. According to the group of Man:

- Experience - lack of experience results in improper performance of certain activities entrusted by the manager,

- Seniority - gaining knowledge and experience through many years of work teaches people to carry out tasks in proper way,

- Qualifications - lack of knowledge skills in handling equipment to perform tasks has great effect on the effects of work.

- Job satisfactions - satisfied employees show greater initiative, reliability and positive climate work, while lack of it may result in lowering organizational efficiency.

\section{Conclusion}

In order to maintain the high efficiency of the anodizing process of aluminium finishing strips, it is necessary to carry out the process in the shortest possible time. However, high level of quality of the finished product must be maintained. The qualitative analysis of aluminium finishing strips showed that:

1. Thickness of coating and stains on the profile are main causes of non-conformances that occurs the most frequent.

2. The main problem of anodizing process was inadequate coating thickness. It was caused by the wrong anodizing time in sulfuric acid. Necessary changes in the process 
parameters, employee trainings and additional technological process control were the most important corrective action.

3. The most important causes of non-conformances in the production process are: ways of hanging profiles, the course of anodizing process, anodizing program, experience of workers, their qualifications, seniority and job satisfaction.

4. The following actions may be proposed to eliminate con-conformances: purchase of measuring and research equipment, implementation of the registry and equipment cards, proper supervision of these documents, the increased technological control of the process, additional laboratory tests, frequent trainings to improve the qualifications, skills and knowledge of people responsible for the process.

5. Other methods and quality management tools can be proposed for the assessment of quality of finishing strips in this company in the future. Their application can also bring a lot of interesting results and can be very effective. However, it should be assessed whether the costs of their use will not exceed the benefits they will bring.

\section{References}

1. A. Hamrol, W. Mantura, Quality analysis. Theory and practice (PWN, Warsaw 2009)

2. E. Kardas, METAL 2017 - Proceedings, 2188 (2017)

3. S.T. Dziuba, M. Ingaldi, M. Kadlubek, 16th International Scientific Conference Proceedings, PTS I-V, 425-432 (2016)

4. M. Ingaldi, S.T. Dziuba, M Kadlubek, 16th International Scientific Conference Proceedings, PTS I-V, 750-758 (2016)

5. P. Sygut, Production Engineering Archives 1/1, 16-18 (2013)

6. P. Szklarzyk, D. Klimecka-Tatar, P. Sygut, T. Lipiński, Production Engineering Archives 4/3, 11-13 (2014)

7. A. Mazur, H. Gołaś, Principles, methods and techniques used in quality management (Publishing House of Politechnika Poznańska, Poznań, 2010)

8. F. Bartes, M. Hodinka, J. Dufka, Proceedings of International Conference on Business and Competitiveness of Companies, 11-16 (2011)

9. D. Y. Negroni, L. G. Trabasso, Proceedings of the 17th International Conference On Engineering Design, Vol 7, Design For X, Design To X, 127-136 (2009)

10. L. K. Tsironis, Benchmarking-An International Journal, 25/1, 47-75 (2018)

11. A. Pabedinskaite, R. Vitkauskas, Proceedings of 6th International Scientific Conference Business And Management Vols I And II, 905-912 (2010)

12. R. Banuelas, J. Antony, M. Brace, Qual. Reliab. Engng., 21, 553-570 (2005)

13. R. Joghee, International Journal Of Quality \& Reliability Management, 34/1, 2-17 (2017)

14. M. Muchova, Management 2012: Research In Management And Business In The Light Of Practical Needs, Proceedings, 266-231 (2012)

15. P. C. Valentina, G. Sorescu, Management Of Technological Changes, 1, 137-140 (2009)

16. Information materials from Company

17. D. Lawinski, Control and analysis of the quality of products in a selected production company (Engineering work under the direction of Edyta Kardas, Czestochowa University of Technology, Czestochowa, 2016) 